DOI: $\square$ https://doi.org/10.15407/techned2020.05.005

\title{
MITIGATION OF OVERHEAD LINE MAGNETIC FIELD BY GRID SHIELD WITH ELECTRICALLY SEPARATED SECTIONS
}

Journal

Publisher

ISSN

Issue

Pages
Tekhnichna elektrodynamika

Institute of Electrodynamics National Academy of Science of Ukraine 1607-7970 (print), 2218-1903 (online)

No 5, 2020 (September/October)

$5-9$

\section{Authors}

\section{V.S. Grinchenko*, 0.0. Tkachenko**}

State Institution "Institute of Technical Problems of Magnetism of the National Academy of Sciences of Ukraine",

19, Industrialna st., Kharkiv, 61106, Ukraine,

e-mail: vsgrinchenko@gmail.com

* ORCID ID : https://orcid.org/0000-0002-6195-3011

** ORCID ID : https://orcid.org/0000-0001-7307-7293

\section{Abstract}

The paper deals with the mitigation of the overhead line magnetic field by a U-shaped grid shield. We consider grid shields made of conductors, which are grouped into electrically separated sections. Conductors within each section are connected in parallel. We vary the number of sections and their topology. Also we vary the parameters of arms of the U-shaped grid shield, namely the length and the number of conductors. We show that the U-shaped grid shield with two electrically separated sections is advisable to use. The one section consists of conductors of a U-shaped shield stem. Another section consists of conductors of both arms connected in parallel. Also we show that the number of conductors in the arm can be reduced to five, if the quantity of metal of the arm is kept. References 10, figures 3, table 1.

Key words: overhead line, magnetic field, shielding, reference level. 
Received: 29.04.2020

Accepted: 06.05.2020

Published: 25.08.2020

\section{References}

1. Electrical installation regulations. Kyiv: The Ministry of Energy and Coal Mining of Ukraine, 2017. 736 p. (Ukr)

2. Rozov V., Grinchenko V. Simulation and analysis of power frequency electromagnetic field in buildings closed to overhead lines. IEEE First Ukraine Conference on Electrical and Computer Engineering /doi.org/10.1109/UKRCON.2017.8100538 . Kyiv, Ukraine, 2017. Pp. 500-503. DOI: https:/

3. Kuznetsov B., Bovdui I., Voloshko A., Nikitina T. Modeling and active shielding of magnetic field in residential buildings located near group of high voltage power lines. IEEE 3rd International Conference on Intelligent Energy and Power Systems . Kharkiv, Ukraine, 2018. Pp. 106-109. DOI: https://doi.org/10.1109/IEPS.2018.8559488

4. Budnik K., Machczynski W. Power line magnetic field mitigation using a passive loop conductor. Poznan University of Technology Academic Journals. Electrical Engineering. 2013. No 73. Pp. 137-145.

5. De Wulf M., Wouters P., Sergeant P., Dupré L., Hoferlin E., Jacobs S., Harlet P.

Electromagnetic shielding of high-voltage cables. Journal of Magnetism and Magnetic Materials . 2007. Vol. 316. No 2. Pp. e908-e911. DOI:

https://doi.org/10.1016/j.jmmm.2007.03.137

6. Rezinkina M.M., Grinchenko V.S. Usage of electromagnetic shields for power frequency magnetic field mitigation in power industry. Tekhnichna Elektrodynamika. 2012. No 3. Pp. 15-16. (Rus)

7. Grinchenko V.S. Mitigation of three-phase power line magnetic field by grid electromagnetic shield. Tekhnichna Elektrodynamika. 2018. No 4. Pp. 29-32. (Rus). DOI: https://doi.org/10.154 $\underline{\text { 07/techned2018.04.029 }}$

8. Dobrodejev P., Volokhov S., Kildishev A. Magnetically quiet shipboard-type electrical equipment: Methods in design and manufacturing. IEEE Oceans Conference Record. Nice, France, 1998. Vol. 3. Pp. 1468-1472. DOI:

https://doi.org/10.1109/OCEANS.1998.726314

9. Grinchenko V., Pyrohova U. Mitigation of overhead line magnetic field by U-shaped grid shield. IEEE 2nd Ukraine Conference on Electrical and Computer Engineering. Lviv, Ukraine, 
2019. Pp. 345-348. DOI:

https://doi.org/10.1109/UKRCON.2019.8879834

10. Grinchenko V.S. Alpha-beta transformation approach for the active shielding of flat power line. Tekhnichna Elektrodynamika. 2014. No 4. Pp. 11-13..

$\underline{\text { PDF }}$

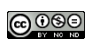

This work is licensed under a Creative Commons Attribution-NonCommercial-NoDerivatives 4.0 International License 